\title{
Application Path Analysis of Social Work Idea on College Students Management
}

\author{
Wen Tang ${ }^{1, a}$, Zhi He , b $^{2}$ \\ ${ }^{1}$ Nanchang University College of Science and Technology, Nanchang, Jiangxi, 330029 \\ ${ }^{2}$ Pingxiang University, Pingxiang, Jiangxi, 337055 \\ ${ }^{a}$ email, ${ }^{b}$ email
}

\section{Keywords: Path Analysis, Social Work, College Students Management}

\begin{abstract}
The core of this study was to analyze the feasibility of school social work student involved in our work on traditional colleges and universities. The author summarizes the development of the school of social work at home and abroad to improve the experience of countries that, school social work student work in order to intervene traditional universities, important prerequisite is to get the recognition and support of education management and administration within the school system. Especially in terms of political systems like China, Traditional Students in Colleges and Universities is developed in a highly centralized planned economy, it does play a role in students' education and management aspects. Therefore, in dealing with this issue must focus on ways and means, must not be quick success. If you get the recognition and support, how reasonable position in the existing education system, but also the intervention must be considered.
\end{abstract}

\section{Introduction}

In recent years, with the rapid social and economic problem of college students increasingly complex and diversified, the traditional work of college students had not effectively meet the needs of students. The main problem faced by former students include learning difficulties, cognitive behavioral bias issues, etc., and the problem now face include single-parent families, divorce, child problems, addiction problems and sexual problems, problems involving multifaceted relationship its complexity requires a wide range of services, but rely on school counseling is unable to meet the needs of individual students.

Overall, the traditional mode of students in colleges and universities produce highly centralized management system and the planned economic system, it plays an important role in the processing time of the student in question. However, with the advent of the establishment of China's market economic system and the popularization of higher education, and social needs more professional and humane management practices, and work our traditional college students has been in use the old model. Concepts and methods of the school of social work, unique, and can meet the needs of a new era, so the traditional college students work will face more new situations and challenges in the new issue. These challenges are mainly focused on the work ethic, clients, work perspectives, objectives and working methods.

Student Work uphold the traditional concept of education that students are immature in some ways, the need for education and management, which is invisible to think students need to rely on education to be growing. It first took the students defined as poor, a subject in need of renovation, it is a relationship of leadership and the led, in reality, is not conducive to start work. And uphold the concept of school social work service, I do not think the students are wrong, but that they encountered obstacles in the growth process, requires specialized knowledge and skills to help. It is based on respect, equality and cooperative attitude to work, easy to be accepted students. Obviously, school social work has a great advantage.

Traditional College Students 'work is mainly a problem for students' individual work, and for the student's approach is a common problem of collective style of preaching, almost no attention to student learning and living environment. The school social work focused not only on individual 
problems, more attention to students' ecosystems. Not only does it show the students note, further investigation and analysis of the situation of their families, schools and communities. It is believed that there is a deviation caused by students not only students cognitive and behavioral problems, and more importantly, their environment is a problem. Aimed at students in-depth analysis of the ecosystem, not only can help students solve the problem behind the problem can dig deeper reason being to help students be eradicated at source, to prevent students again plagued.

Traditional College Students Work to take the perspective of the issue, focusing on students' problems, it is very easy to fall into the tag mode, the student is not conducive to solving the problem. And take advantage of school social work perspective, it is each person, group, organization and community has its inherent capabilities, including talent, knowledge, social support and resources said. As long as the appropriate conditions exist, it can constructively play to their capabilities. ? It is the traditional problem of different perspectives, starting it from the student's bright spot, not isolated to focus on the problem. This benefit is the ability to transfer positive energy to the students, to stimulate students' initiative and creativity.

\section{Necessity of Social Work Intervention on College Student Management}

Currently the subject of a work of college students ideological and political education, which is mainly inherited from the planned economy mode of education to the party committee-based system, supplemented by administrative, student at the specific implementation, again for the first-line instructor students carry out ideological and political education and daily management to help students establish a group of love, love the party, patriotic concept of collectivism, students dedication, this mode of student work in political activities as the main body of the traditional simple plan economy can also take on students' daily educational work, but with the changes in an open economy, social transformation, the upper ideological pluralism access to information channels, are in school and are not thought to be mature students early faced with the role change, adaptation to the environment, self-development and interpersonal coordination multifaceted challenges, at the same time, college students overloaded with work to take on a lot of social transformation due to the shock and pressure caused by college students, which makes Universities student workload is too heavy, is beyond the scope of its own, not just only by virtue of the school's resources to solve the problem, many of the problems are related to the social system, the community and the families of students in close contact, thus requiring broader contact school social work social resources, the use of more humane, rationalization of communication methods and educational methods to guide students, students empowerment, increased energy, higher education is no longer the center of gravity is simply tell the students what to do, but to teach students a species deal with the problem and ways to deal with people, high school students in the school of social work is no longer the object of preaching, but has been in a dominant position, is active, the school social worker is to guide students how to solve problems and achieve the ultimate helpful buffet,

\section{Path Analysis of Social Work College Application on Student Management}

Some scholars have suggested that under the current system of colleges and universities, school social work intervention of Students' management are two: First, the endogenous pathway, the second is extrinsic pathway.

Not a strong team of professionals, school social work can not be carried out. Social work to intervene College Student Management, currently a possible way is to first improve the overall level of professional social workers. We can set up the school of social work courses in the existing system of social work professional courses and universities, training required for professionals. In addition, full-time student counselor is actually playing the role of quasi-school social workers. But these counselors knowledge base and different professional backgrounds, most do not have the professional skills to help others. This can be done by training some professional knowledge, learning and skills, to enhance the sense of service and professional level this workforce. 
School Social Work College Student Management, the need for services and service providers to rely on. You can set up social work office or workstation in universities, which not only enables social work services standardization and regular, but also conducive to the management and quality control. In addition, in the course of doing professional social work, look for and find organizational resources are a very important part. The establishment of service projects and launch services, but also conducive to a wide range of communication and contact, for a wide range of social resources.

That is the path by means of external intervention exogenous forces directly Institutional Arrangement school social work. Under China's current university system, the state and the government departments at all levels to play a pivotal role. Therefore, the school of social work intervention College Student Management also need government support and strong policies to promote. Social work is not just a method, a professional, but also a social and professional. In 2004, social workers officially incorporated into the Chinese Professional directory, that is, as a new career is established; in July 2006, the Ministry of Personnel Ministry of Civil Affairs jointly issued a 'professional level social workers evaluate the Interim Provisions of social workers professional level exam implementing measures in 2008, began holding an annual national assistant social work Social work professional qualification exams, marks the establishment of the social work profession and professional certification system. In 2010, the construction of social work personnel were included in the national long-term talent development program (2010-2020) (as one of the main tasks. With the advancement of social work professional occupation process, the government should increase efforts to support the establishment of specialized social work services can be stationed full-time social workers into the school while preparing to give a fixed social workers, and give full consideration and professional titles use.

A new system should be organized in the existing system and stabilize, requires a series of related policy support can be achieved. Apart led by the Government, the implementation and effective operation of the school of social work also needs to be supported by the leadership of the various departments and schools at all levels of policy. In addition, the development of school social work needs of various social organizations, particularly non-governmental organizations to support non-governmental organizations should be important providers and implementers school social work service, it can continue to develop all kinds of personnel, especially for the College for Students a variety of services. Social work in Western countries as well as Hong Kong, Taiwan and other Chinese regions have developed more mature, which gives the mainland has provided valuable experience for reference. However, school social work in carrying out the university is still in the start-up and trial stage, still we need to go through a continuous exploration and practice of the process; and, in the long-running process, the university has formed a relatively complete student management system, social work the intervention will inevitably have doubts. This aspect requires constant efforts of social workers, continuing to explore and summarize, but also look forward to all sectors of society including the management of college students understand the trust and support of social work. Reason to believe that the concept of methods and techniques through professional practice of social work, to further strengthen and promote the college student management effectiveness, and create a better environment and conditions for the healthy growth and overall development of students. Feasibility and Path of Social Work College Student Management.

\section{Conclusion}

In the school of social work with lightning speed development, and accelerate traditional college students to enter the work, there must be a lot of questioning voice. Throughout all the world, every new things to replace the original system or to be rich and optimization, will be subject to the old question and dragging kill system, which is an instinctive reaction of nature. The current major universities training social work profession the number of students and the quality point of view, still far from reaching the level of Western countries, school social work, their ability to ability to perform the task of school social work is not known. Faced with such voices of doubt, the existence of some truth. But think about it, this is the school of social work injustice, we can not at the initial 
stage of the development of premature school social work schools to judge the true value of social work, which is obviously not logical development of things.

\section{References}

[1] Castin L.B. School Social Work as Specialized Practice .Social Work, 1981.

[2] Marion Huxtable, Eric Blyth. School Social Work Worldwide. National Association of Social Workers, Washington, DC, 2002.

[3] J.J.Alderson.ModeIs of School Social Work Practice. R.C.Sarri and F.F.Maple (eds) .The School inthe Community [C]. Washington, DC:. National Association of Social Workers, 1988.57-74.

[4] Sheng Yueming, Pang Juan. Construction of new college students working on a system of ideological and political work and social work study [J]. Theorists, 2005, (1).

[5] Ge Jun, Shi Biyu. plight of our school social work carried out in the face of - school social workers in Shenzhen Pilot Case [J] heritage, 2010 (7). 